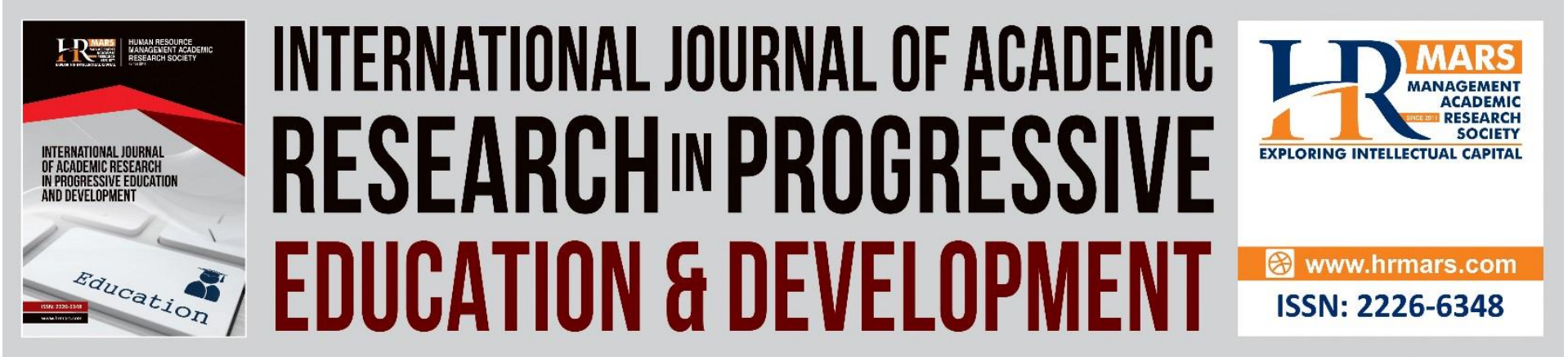

\title{
Paving the Way for Mandarin Language Learning: MOOCs Style
}

Goh Chin Shuang, Turisiana Ahmad Buhari, Lee Ai Chat

To Link this Article: http://dx.doi.org/10.6007/IJARPED/v10-i3/11091 DOI:10.6007/IJARPED/v10-i3/11091

Received: 07 July 2021, Revised: 29 July 2021, Accepted: 15 August 2021

Published Online: 08 September 2021

In-Text Citation: (Shuang et al., 2021)

To Cite this Article: Shuang, G. C., Buhari, T. A., \& Chat, L. A. (2021). Paving the Way for Mandarin Language Learning: MOOCs Style. International Journal of Academic Research in Progressive Education and Development, 10(3), 1321-1338.

Copyright: (C) 2021 The Author(s)

Published by Human Resource Management Academic Research Society (www.hrmars.com)

This article is published under the Creative Commons Attribution (CC BY 4.0) license. Anyone may reproduce, distribute, translate and create derivative works of this article (for both commercial and non-commercial purposes), subject to full attribution to the original publication and authors. The full terms of this license may be seen

at: http://creativecommons.org/licences/by/4.0/legalcode

Vol. 10(3) 2021, Pg. 1321 - 1338

http://hrmars.com/index.php/pages/detail/IJARPED

JOURNAL HOMEPAGE

Full Terms \& Conditions of access and use can be found at http://hrmars.com/index.php/pages/detail/publication-ethics 


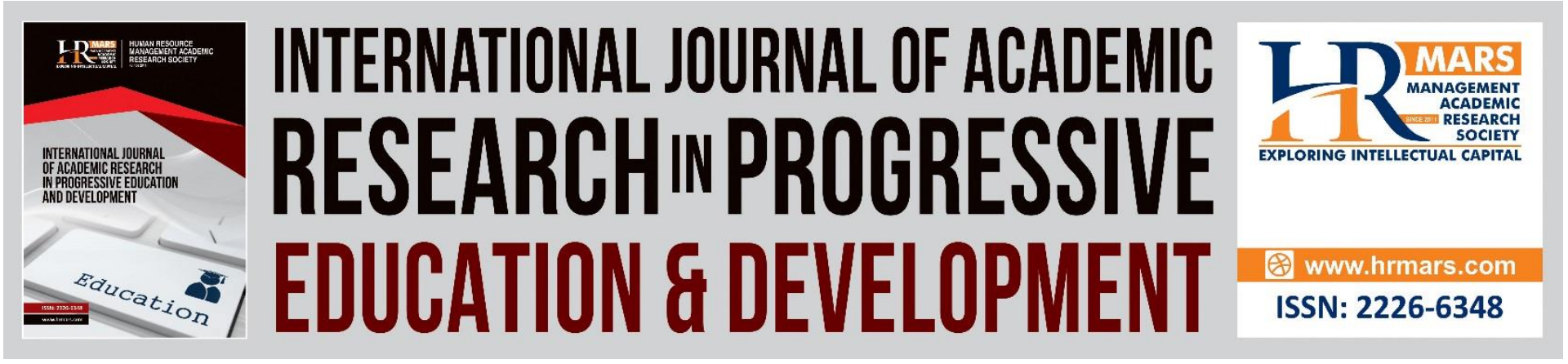

\title{
Paving the Way for Mandarin Language Learning: MOOCs Style
}

\author{
Goh Chin Shuang, Turisiana Ahmad Buhari, Lee Ai Chat \\ Akademi Pengajian Bahasa, Universiti Teknologi MARA, 40450 Shah Alam, Selangor, \\ Malaysia \\ Email: cassgoh@gmail.com, turisianab08@gmail.com, leeaichat@gmail.com
}

\begin{abstract}
The design and implementation of MOOCs with focus on language learning has yet to be widely explored in Malaysia. The ability to speak Mandarin is an advantage and any means to facilitate the learning of Mandarin is sought after. The paper centers on the use of Introductory Mandarin 1 as an interactive MOOCs Mandarin Language Learning for Elementary Mandarin. This research explores the use of Introductory Mandarin 1 as a method to strengthen learners' four language skills, improve learners' vocabularies with visual-verbal-auditory features, and create a flexible, enjoyable, flip and active learning environment via MOOC platform. Using Gagne's Model of Instructional Design as the theoretical framework, this paper reports a quantitative survey study involving 265 students across 8 faculties at Universiti Teknologi MARA. These students enrolled voluntarily in Elementary Mandarin 1 as a supplementary learning tool. Survey results showed that learners' Mandarin proficiency, specifically communicative language skills, such as listening, pronunciation, writing, speaking, and vocabulary is improved. The research also confirmed the useability of MOOC as a supplementary material to assist the teaching and learning of Mandarin. Possible future research can focus on adding in aspects of assessments into MOOC or the feasibility of turning $\mathrm{MOOC}$ content into micro-credential courses.
\end{abstract}

Keywords: MOOC, Elementary Mandarin, Communicative Language Skills, Online Distance Learning (ODL), Design-Based Research

\section{Introduction}

In 2017, an estimated 23 million users signed up for their first MOOC in which totaled to 81 million later that year (Shah, 2018). In line with the popularity of MOOCs, many tertiary institutions worldwide have joined in this phenomenon by designing and transferring their own courses to MOOC platforms. The Malaysian higher education, with the mission to build the Malaysian education brand globally, has developed and inaugurated its own series of MOOCs. According to Malaysia Education Blueprint 2015-2025 report, produced by the Ministry of Education (2015), the vision of the education blueprint is to aspire our education system toward harnessing online learning, enhancing the quality of teaching and learning, lowering the cost of delivering teaching and learning, and bringing Malaysian expertise to the 
global community. In addition, to make online learning an integral component of higher education and to promote lifelong learning, the Ministry of Education (MOE) encourages the tertiary institution to begin with the conversion of common undergraduate courses into MOOCs, with the requirement of up to $70 \%$ of programs to use blended learning models. To keep abreast with the new trends in teaching instruction, Universiti Teknologi MARA (UiTM), as one of the public universities has launched several undergraduate courses via MOOCs since 2014. Concurrently, designing and developing good MOOCs that meet the learners' needs have become part of modern-day language teaching and learning practice. In line with it, the researchers developed the Introductory Mandarin 1 as an interactive multimedia e-learning courseware for the teaching and learning of Elementary Mandarin I via MOOC platform.

\section{Problem Statement}

Since the term Massive Open Online Courses (MOOCs) was first introduced in 2008 by Dave Cormier, the delivery of courses using $\mathrm{MOOC}$ platform has attracted growing attention and scrutiny in higher education (Carver \& Harrison, 2013). An increasing number of tertiary institutions offer their MOOCs with the intention to make their courses more accessible to global learners with Internet access. In Malaysia, the MOE initiated the move for Malaysia's MOOCs to be integrated into the higher education system beginning year 2014 with the aim to globalise Malaysian higher education institutions. Furthermore, there is also an intention to bring Malaysian expertises to the global community by increasing the quality standard of courses offered to international level (Ministry of Education, 2015). Nevertheless, the design and implementation of MOOCs with focus on language learning has yet to be widely explored in Malaysia.

\section{Research Objectives}

The advent of technology has made it possible for lessons to be conducted via the Internet and other digital media. Thus, the foreign language teacher or practitioner can transform teaching materials or contents into a different format to use on a variety of portable devices or platforms such as via MOOC (Massive Open Online Course) as well as diversify their teaching methods such as conducting online communication activities via MOOC platform after classroom teaching. The attempt to develop Introductory Mandarin 1 serves as a good reference on the principles of teaching and learning Mandarin among non-native and foreign/ third language learners.

The objectives of this research are (1) to explore the use of Introductory Mandarin 1 as a method to strengthen learners' four language skills (speaking, listening, reading, and writing), (2) to improve learners' vocabularies with visual-verbal-auditory features, and (3) to create a flexible, enjoyable, interactive, flip and active learning environment for learners via MOOC platform.

\section{Methodology}

The research involves the design and development of the Introductory Mandarin 1, an interactive multimedia e-learning courseware, for the teaching and learning of Elementary Mandarin I via MOOC platform. The Introductory Mandarin 1 in particular is a self-developed product of the researchers in this study. The teaching course Introductory Mandarin 1 is developed by using e-learning and m-learning authoring tools such as Adobe master software, 
iSpring, Camtasia and movie maker, html 5, mobile apps, and others. In other words, multimedia features such as audio, video, image, text, graphic, animation, and other similar features are employed. Students/Learners can study Mandarin via their mobile phones or laptops. The learning platform chosen for the implementation of Malaysia's MOOCs is the Openlearning platform. The Introductory Mandarin 1 specifically, is accessed on the same platform (https://www.openlearning.com/courses/introductory-mandarin-i-20).

\section{Participants and Setting}

The study was carried out in Universiti Teknologi MARA, a public university in Malaysia. The participants who participated voluntarily were undergraduates and non-native speakers of Chinese language who had enrolled in Elementary Mandarin 1 at UiTM. They enrolled in Introductory Mandarin 1 course via Openlearning platform and used the Introductory Mandarin 1 materials as a supplementary learning tool to enhance their Mandarin proficiency outside the classroom. The student population included male and female students in different faculties. The sample comprised 265 students from nine classes in eight faculties at UiTM, Shah Alam and Puncak Alam, Selangor, i.e., Accountancy (AC), Architecture, Planning, and Surveying (AP), Academy of Language Studies (APB), Business and Management (BM), Computer and Mathematical Sciences (CS), Civil Engineering (EC), Education (ED) and Electrical Engineering (EE).

These participants served not only as the recipients of the MOOCs multimedia-enhanced program but also the respondents for the research. One Mandarin class was selected from each faculty except for two Mandarin classes from the AP faculty. Throughout the entire semester, these students attended their Mandarin classes in classrooms and MOOC elearning materials developed for Introductory Mandarin 1 were used as a supplementary instructional tool to enhance students' Mandarin acquisition. At the end of the semester, all students from the selected classes were required to share their perceptions on the use of multimedia e-learning materials of Introductory Mandarin 1 via the Openlearning platform which constituted as a supplementary instructional tool in learning Mandarin.

All students who participated in the study were asked to respond to the research questionnaire. The breakdown of the respondents is as follows: 25 students from Accountancy (AC), 70 students from Architecture, Planning, and Surveying (AP), 30 students from Academy of Language Studies (APB), 28 students from Business and Management (BM), 34 students from Computer and Mathematical Sciences (CS), 26 students from Civil Engineering (EC), 16 students from Education (ED), and 36 students from Electrical Engineering (EE). A total of 265 questionnaires were distributed for the study. The 265 participants consisted of 92 male students, and 173 female students as shown in Table 1. 
INTERNATIONAL JOURNAL OF ACADEMIC RESEARCH IN PROGRESSIVE EDUCATION AND

DEVELOPMENT

Vol. 10, No. 3, 2021, E-ISSN: 2226-6348 @ 2021 HRMARS

Table 1

Details of Participants

\begin{tabular}{lllll}
\hline & Faculty & $\begin{array}{l}\text { Male } \\
\text { Respondents }\end{array}$ & $\begin{array}{l}\text { Female } \\
\text { Respondents }\end{array}$ & $\begin{array}{l}\text { Number of } \\
\text { Respondents }\end{array}$ \\
\hline 1. & Accountancy (AC) & 2 & 23 & 25 \\
2. & $\begin{array}{l}\text { Architecture, Planning \& Surveying (AP) } \\
\text { *2 classes }\end{array}$ & 26 & 44 & 70 \\
3. & Academy of Language Studies (APB) & 6 & & \\
4. & Business \& Management (BM) & 6 & 24 & 30 \\
5. & Computer \& Mathematical Sciences (CS) & 6 & 22 & 28 \\
6. & Civil Engineering (EC) & 16 & 28 & 34 \\
7. & Education (ED) & 10 & 10 & 26 \\
8 & Electrical Engineering (EE) & 20 & 6 & 16 \\
& Total & 92 & 16 & 36 \\
\hline
\end{tabular}

\section{Introductory Mandarin 1 Multimedia e-learning Courseware}

The teaching course Introductory Mandarin 1 was developed by using e-learning and $\mathrm{m}$ learning authoring tools such as Adobe master software, iSpring, Camtasia and movie maker, html 5, mobile apps, and others. In other words, multimedia features such as audio, video, image, text, graphics, and animation are employed. Students/Learners can study Mandarin via their mobile phones or laptops.

The multimedia e-learning courseware was developed based on the prescribed Mandarin 1 textbook with 1 topic and Hanyu Pinyin intended for one topic per week. All materials developed were uploaded onto www.openlearning.com. The Multimedia e-learning courseware included various features to enhance Mandarin learning as described below:

a) Course Introduction video

The video for brief introduction intends to help learners familiarise with the content that they will be learning throughout the 14 weeks and thus learners will be able to manage their own study plan.

\section{b) Hanyu Pinyin}

Romanised version of notes, exercises, and Internet links resources are provided for students to do revision at their own time and pace.

c) Study materials ( Hanyu Pinyin +Topic 1 to Topic 13)

Every topic has the following features and contents:

i) Learning objectives: The learning outcome that the learner should achieve after completing the topic.

ii) Video Teaching: Each topic consists of two or more video teachings. From the video teachings, learners will be taught the learning focuses of the topic. After mastering the learning focuses, learners can continue to gain more knowledge from other parts of the courseware.

iii) Teaching notes: These are used to train learners how to use a particular language structure to express intentions. All the teaching notes have multimedia features such as image, 
DEVELOPMENT

Vol. 10, No. 3, 2021, E-ISSN: 2226-6348 @ 2021 HRMARS

animation, audio, and translation features. The main aims of the audio files are to enhance the learner's listening and speaking skills, and to increase their knowledge of grammar.

iv) Grammar: Notes given on Mandarin grammar are text based and images. In addition, typical grammatical errors made by students were emphasised and explanations are given to highlight the differences between English and Mandarin grammar.

v) Vocabulary: Vocabulary practice and drills are provided in each chapter. The vocabulary on the chart has visual-verbal-auditory features. These are for learners to read, verbalise and listen to the pronunciation of each word and compare their pronunciations. With the aid of the vocabulary charts, learners can grasp the contents of the various situational dialogues in each chapter. With a click on the "speaker" icon, learners can listen to the pronunciation of each new word in the target language.

vi) Dialogues and videos: Each topic consists of at least two different dialogues. Each dialogue is in a text file with audio and video clips. All video clips have Mandarin subtitles in Romanised Hanyu Pinyin and the Chinese characters. Representation of the sample dialogues in the form of video clips are found to be very useful to students, particularly in helping them to practise listening, speaking and reading. With movie clips, the textual contents of the book are dramatised and learners can listen to the digital audio of native speakers' voices, in particular, the pronunciation of words and intonation of phrases and sentences.

vii) Quiz: With the drill and practice quiz for each topic, students can see or listen to the information at any time by pressing a button or icon on the screen. Furthermore, all quizzes included can strengthen the students' four learning skills namely listening, reading, speaking and writing.

viii) Internet link: Links to Internet resources relevant to each theme are included in each topic for students to enhance their vocabulary through the extra information related to the themes being learned.

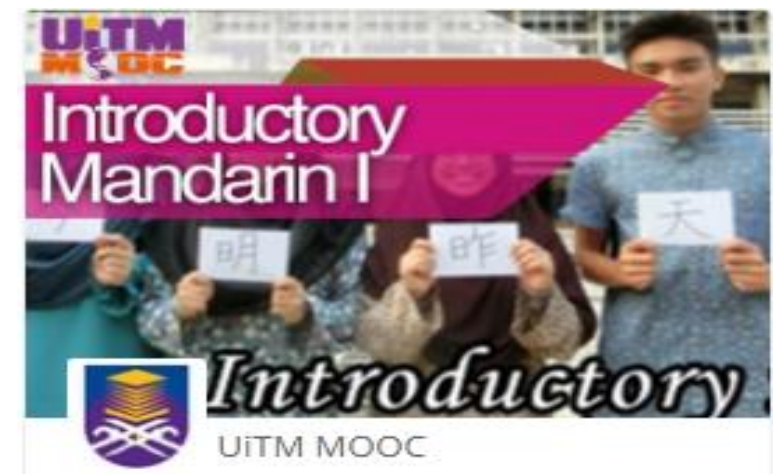

Introductory Mandarin I

1661 Students

$$
\text { On now }
$$

Introductory Mandarin 1 cover page
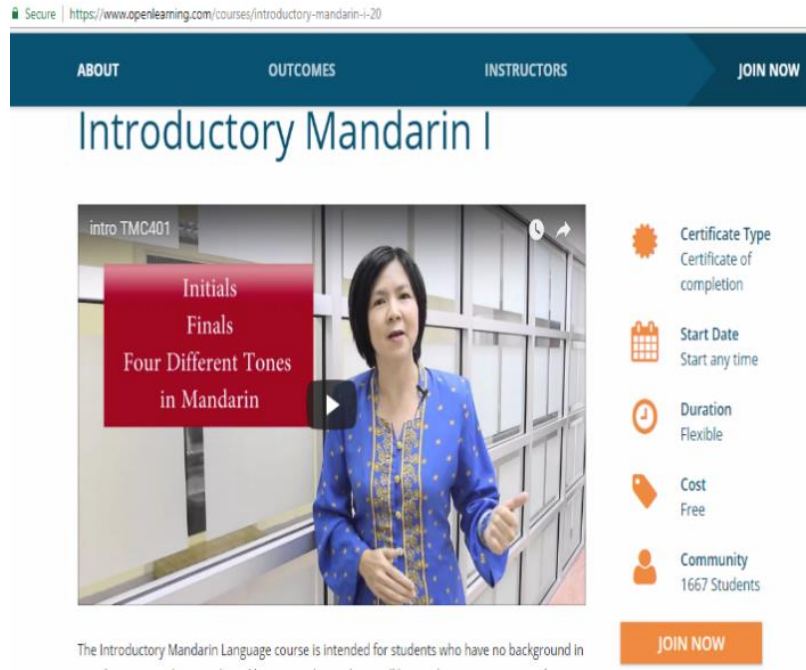

Introductory Mandarin 1 registration page

Figure 1. Introductory Mandarin 1 cover and registration page screen design 
DEVELOPMENT

Vol. 10, No. 3, 2021, E-ISSN: 2226-6348 @ 2021 HRMARS

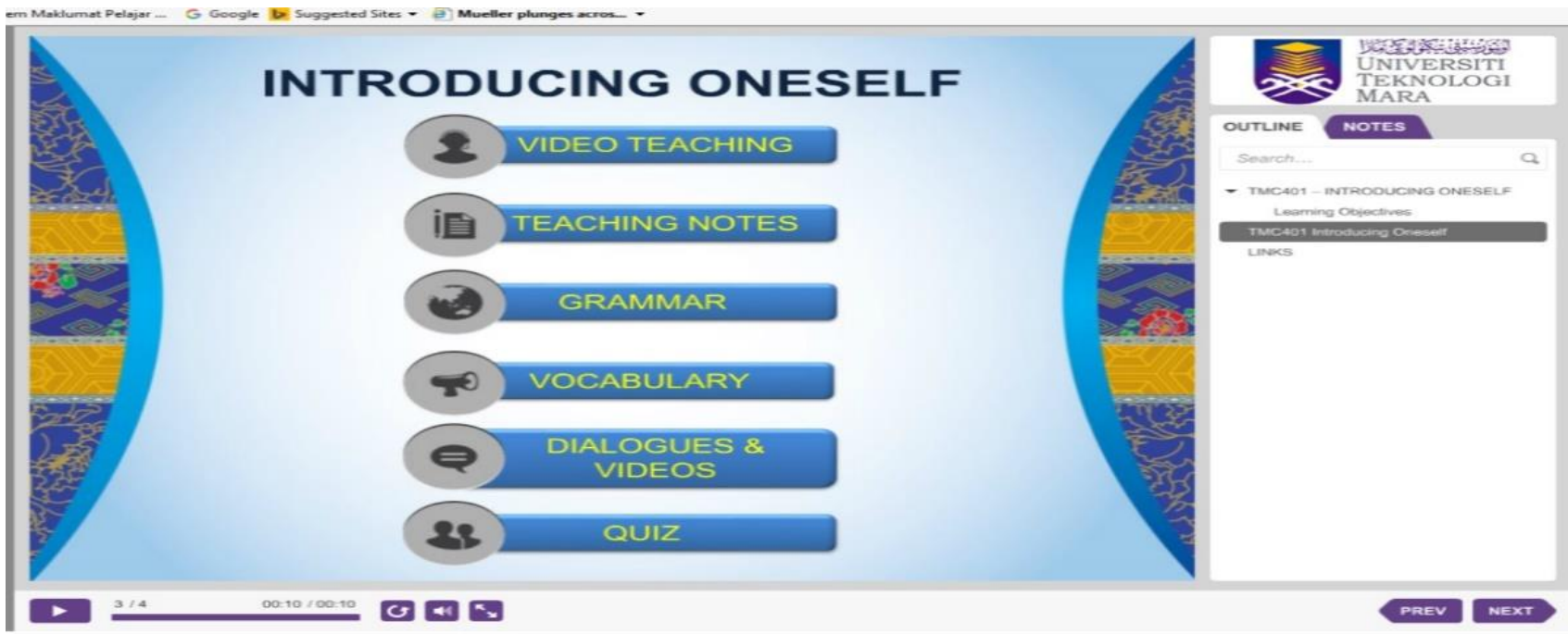

Figure 2. Main page screen design

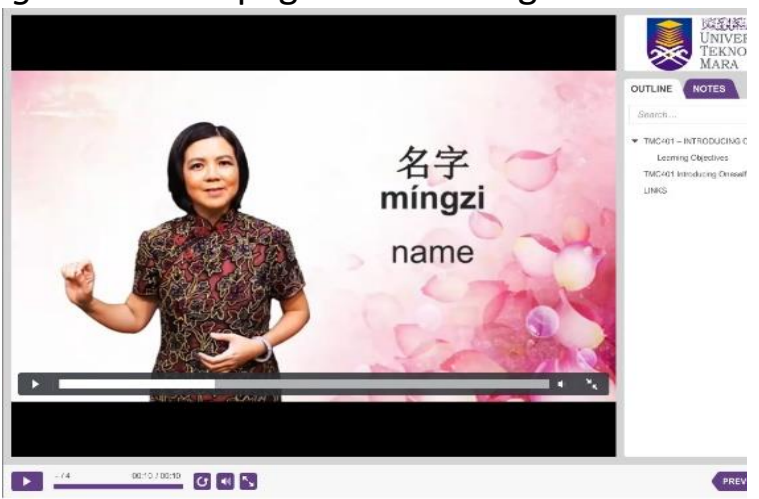

Video teaching

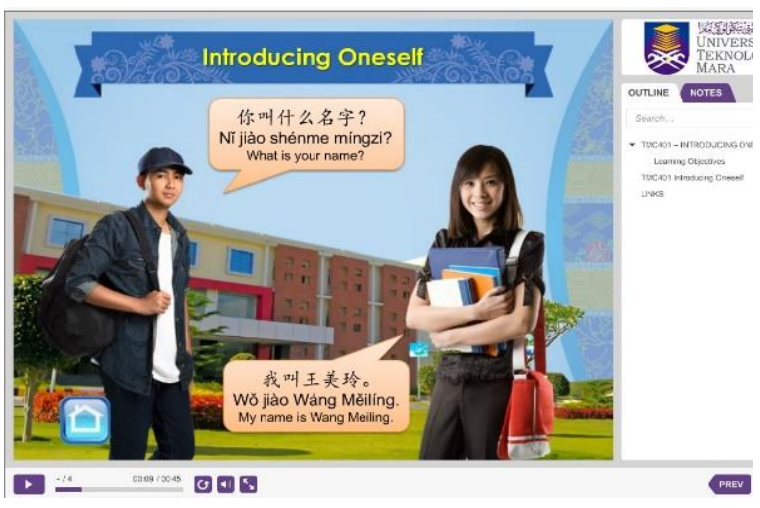

Teaching note

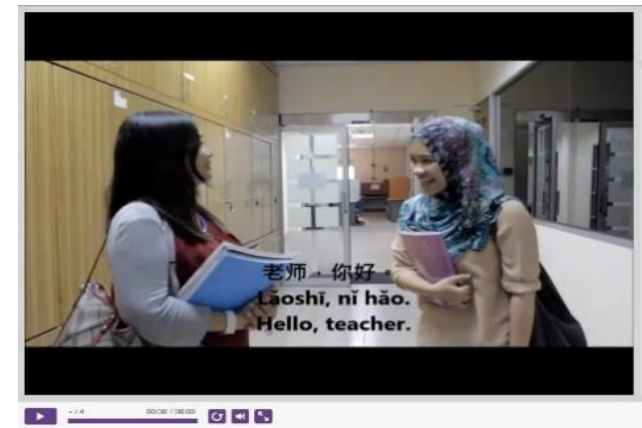

Situational dialogues

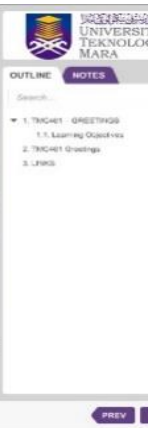

Back Skip Quiz

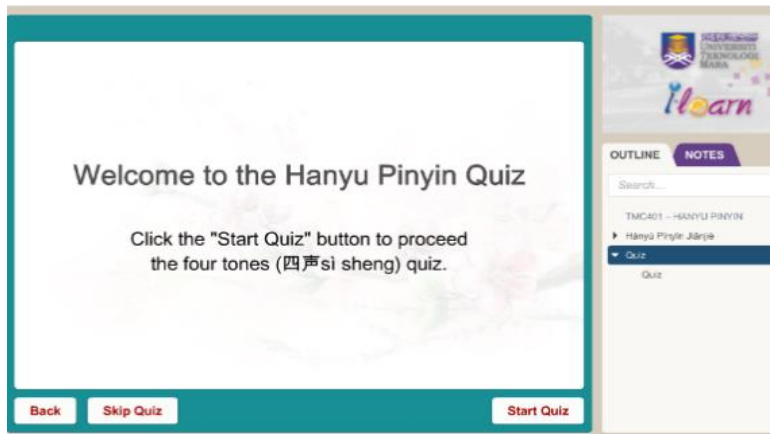

Figure 3. Example of Introductory Mandarin 1 contents

\section{Instruments}

The questionnaire consisted of 25 questions in two main sections. Section I (5 questions) sought the respondents' personal information (demographics). Demographic questions were used to collect general information about participants: gender, age group, faculty and class group, time spent to learn Mandarin. Section II (20 questions) required the respondents to evaluate the e-learning materials entitled Introductory Mandarin 1 with a Likert scale ranging from 1 to 5 ( 1 = strongly disagree, 2 = disagree, 3 = not sure, $4=$ agree, $5=$ strongly agree). The feedback to both online and print versions of the questionnaire were used in the study. 
DEVELOPMENT

Vol. 10, No. 3, 2021, E-ISSN: 2226-6348 @ 2021 HRMARS

\section{Theoretical Framework of the Study}

The MOOC multimedia e-learning instructional materials for Introductory Mandarin 1 in this research were self-developed by the researchers. Some authoring tools such as Adobe master software, iSpring, Camtasia and movie maker, html 5, and mobile apps were employed as they are compatible with most digital devices and also enable delivery of all interactive multimedia applications like graphics, sounds, video, animation, and texts.

The theoretical framework of this instruction material was developed with reference to Gagne's Nine Events of Instruction Instructional Design Model to ensure effective use of media in instructions. According to Gagne, there are nine elements corresponding to cognitive process as summarised below.

(i) Gaining attention (reception) - It is crucial to help learners focus on the subject being learned and task at hand. Utilisation of a combination of graphics, animation, and sound elements were intended to attract the attention of users and motivate them. The interactive presentation was designed to stimulate learners' interest in learning Mandarin.

(ii) Informing the learning objective (expectation) - The material should inform its users of the targeted learning outcomes for Elementary Mandarin I. With a concrete idea of the overall learning objectives, learners will be able to focus on the main contents of the lessons. Every chapter of the MOOC e-learning materials consisted of a learning objective icon to inform the learners of the learning objectives and outcomes of the chapter.

(iii) Stimulating recall of prior learning (retrieval) - The material should be able to stimulate learners to recall their prior knowledge related to the subject matter while gaining new knowledge. Hypertext technology was incorporated into the multimedia e-learning materials of Introductory Mandarin 1 as it would allow learners to link freely from one chapter to another when selecting topics for revision.

(iv) Presenting the stimulus (selective perception) - The material should be able to initiate new information. Exercises and language drills that were designed according to the progressive learning of the learners' levels were incorporated into the materials. Concrete examples and exercise questions similar to assessments were given. Additionally, participation in online forum activities would help learners to acquire knowledge of Mandarin.

(v) Providing learning guidance (semantic encoding) - The material should be able to assist learners to structure all new information in ways that can be stored and remembered. Various exercises and drills closely related to the four language skills, i.e. reading, writing, listening and speaking, were incorporated into the materials. In addition, the structure of hyperlinks with graphics and animation allowed learners to do revision easily. Links to extra Internet resources were provided for each chapter to encourage students to acquire extra information on Mandarin for each topic.

(vi) Eliciting performance (responding) - The materials should be able to stimulate learners to respond actively to icons and hyperlinks incorporated in order to achieve the learning objectives. The listening, speaking, and reading with auditory are features that would elicit results that could not be achieved through workbooks or other forms of textual exercises. 
(vii) Providing feedback (reinforcement) - The materials should have a mechanism which ensures that learning has occurred. Students were provided with ways to give feedback to the materials via online chat. Furthermore, online forum activities with provisions for concrete and prompt feedback to students were also incorporated.

(viii) Assessing performance (retrieval) - The materials should be able to determine whether users' performance is appropriate. Learners should be able to tell whether their attempted answers are correct or incorrect. In online forum activities, students received correct answers from other students or their lecturer. As for language assessment, the materials reinforced and assessed four basic language skills, i.e. learners' reading, writing, listening, and speaking abilities. Exercises for assessments, quizzes, and tests were also incorporated.

(ix) Enhancing retention and transference (generalization) - The materials should be able to allow learners to retain newly acquired knowledge and turn the knowledge into longterm memory. The contents, coupled with exercises and drills, were intended to strengthen learning. By actively engaging in course materials and course activities in MOOC Introductory Mandarin 1, learners/students could easily transfer the Mandarin knowledge already acquired to their long-term memory.

\section{Results and Discussions}

Based on the data gathered from Section I of the questionnaire, all the 265 respondents from the eight faculties who participated in the present study did not have any experience of using Introductory Mandarin 1 materials as learning aids in learning Mandarin. In other words, all respondents who participated in this research had no prior exposure to learning Mandarin by using a multimedia e-learning instructional tool in MOOC platform and had no experience of being in a learning environment which uses this teaching methodology. The quantitative findings were derived with the aid of the Statistical Package for Social Sciences (SPSS), which generated the descriptive statistics of the data. 
INTERNATIONAL JOURNAL OF ACADEMIC RESEARCH IN PROGRESSIVE EDUCATION AND

DEVELOPMENT

Vol. 10, No. 3, 2021, E-ISSN: 2226-6348 @ 2021 HRMARS

Table 2

Descriptive Statistics for Demographic profile of respondents learning Introductory Mandarin 1

\begin{tabular}{|c|c|c|c|}
\hline Item & Demographics & Frequency & Percentage (\%) \\
\hline \multirow[t]{2}{*}{ Gender } & Male & 92 & 34.7 \\
\hline & Female & 173 & 65.3 \\
\hline \multirow[t]{9}{*}{ Faculty } & $A C$ & 25 & 9.4 \\
\hline & AP & 70 & 26.4 \\
\hline & APB & 30 & 11.3 \\
\hline & $\mathrm{BM}$ & 28 & 10.6 \\
\hline & CS & 34 & 12.8 \\
\hline & $\mathrm{EC}$ & 26 & 9.8 \\
\hline & ED & 16 & 6.0 \\
\hline & $\mathrm{EE}$ & 36 & 13.6 \\
\hline & Total & 265 & 100 \\
\hline \multirow[t]{5}{*}{ Age } & $18-20$ & 21 & 7.9 \\
\hline & $21-23$ & 231 & 87.2 \\
\hline & $24-26$ & 12 & 4.5 \\
\hline & $27 \&$ above & 1 & 0.4 \\
\hline & Total & 265 & 100 \\
\hline \multirow{3}{*}{$\begin{array}{l}\text { Used other websites } \\
\text { before taking } \\
\text { Introductory Mandarin } 1\end{array}$} & Yes & 13 & 4.9 \\
\hline & No & 252 & 95.1 \\
\hline & Total & 265 & 100 \\
\hline \multirow{5}{*}{$\begin{array}{l}\text { Hours to learn } \\
\text { Introductory Mandarin } 1 \\
\text { (per week) }\end{array}$} & less than 1 hour & 59 & 22.3 \\
\hline & $1-3$ hours & 180 & 67.9 \\
\hline & 4-6 hours & 25 & 9.4 \\
\hline & $7-9$ hours & 1 & 0.4 \\
\hline & Total & 265 & 100 \\
\hline
\end{tabular}

The profile of respondents is given in Table 2. The questionnaire was administered to 265 students on Shah Alam campus and a satellite campus of UiTM. Overall, 265 students provided valid data. Of the 265 students, 92 (34.7\%) were male and 173 (65.3\%) were female.

The nine classes were selected from eight faculties at UiTM, Shah Alam. Only one Mandarinlearning class was selected from each faculty except the Faculty of Architecture, Planning, and Surveying (AP). The average number of students in each class was 20 or more, except for one class from the Faculty of Education (ED), which had only 16 students. 
The participants ranged mostly from 18 to 26 years old and one participant claimed to be 27 or above. Next, $231(87.2 \%)$ of participants were in the $21-23$ age group, and 21 (7.9\%) were between 18-20 years old. Only 12 (4.5\%) participants were between 24-26 years of age and $1(0.4 \%)$ participant was in the age group of 27 and above.

With reference to Table 2, more than two-thirds (180 or $67.9 \%$ ) of the participants spent 1-3 hours per week to learn Mandarin whereas 59 (22.3\%) students spent less than 1 hour on learning Mandarin. Meanwhile, 25 (9.4\%) students spent 4-6 hours and $1(0.4 \%)$ student spent 7-9 hours per week on learning Mandarin.

To sum up, from the data analysis, female students' ratio outnumbered the male students' ratio. The average number of students in each class was quite high considering that there were more than 20 students. The majority of students were between 18-23 years old in which represents the average age range for students studying in university. The data also showed that the majority of students did not have Mandarin e-learning learning experience and most of the students spent only 1-3 hours for studying Mandarin per week. It meant that most of the students spent average/less time on studying Mandarin.

The researcher assessed the usability of Introductory Mandarin 1 from two aspects, namely its contents and its relevance to the teaching and learning of Mandarin. Additionally, the researchers used Likert-scales 1-5 to categorise the score 1-2 points as 'disagree', 3 points as 'not sure' and 4-5 points as 'agree'.

The detailed results of the participants' perceptions toward the contents of Introductory Mandarin 1 are shown in the table below. 
INTERNATIONAL JOURNAL OF ACADEMIC RESEARCH IN PROGRESSIVE EDUCATION AND

DEVELOPMENT

Vol. 10, No. 3, 2021, E-ISSN: 2226-6348 @ 2021 HRMARS

Table 3

Contents of multimedia e-learning MOOC: Introductory Mandarin $1 \quad n=265$

\begin{tabular}{|c|c|c|c|c|c|c|}
\hline Item & $\begin{array}{l}\text { Strongl } \\
\text { y } \\
\text { Disagre } \\
\text { e } \\
\% \text { (no.) }\end{array}$ & $\begin{array}{l}\text { Disagre } \\
\text { e } \\
\% \text { (no.) }\end{array}$ & $\begin{array}{l}\text { Not } \\
\text { sure } \\
\% \text { (no.) }\end{array}$ & $\begin{array}{l}\text { Agree } \\
\% \text { (no.) }\end{array}$ & $\begin{array}{l}\text { Strongly } \\
\text { Agree } \\
\% \text { (no.) }\end{array}$ & $\begin{array}{l}\text { Mean/ } \\
\text { SD }\end{array}$ \\
\hline $\begin{array}{l}\text { Contents } \\
\text { (compliance } \\
\text { syllabus) }\end{array}$ & $1.1(3)$ & $0.8(2)$ & 7.2 (19) & $\begin{array}{l}55.8 \\
(148)\end{array}$ & $35.1(93)$ & $\begin{array}{l}4.26 / \\
0.710\end{array}$ \\
\hline $\begin{array}{l}\text { Learning objectives } \\
\text { (clear) }\end{array}$ & $1.1(3)$ & $2(95)$ & $\begin{array}{l}10.2 \\
(27)\end{array}$ & $\begin{array}{l}60.0 \\
(159)\end{array}$ & $27.9(74)$ & $\begin{array}{l}4.18 / \\
0.706\end{array}$ \\
\hline $\begin{array}{l}\text { Topic syllabus } \\
\text { (clear \& complete) }\end{array}$ & $1.5(4)$ & $0.4(1)$ & $\begin{array}{l}10.6 \\
(28) \\
\end{array}$ & $\begin{array}{l}56.2 \\
(149) \\
\end{array}$ & $31.3(83)$ & $\begin{array}{l}4.22 / \\
0.740 \\
\end{array}$ \\
\hline $\begin{array}{l}\text { Support materials } \\
\text { (provided) }\end{array}$ & $0.4(1)$ & $0.8(2)$ & $\begin{array}{l}12.1 \\
(32)\end{array}$ & $\begin{array}{l}53.6 \\
(142)\end{array}$ & $3.2(88)$ & $\begin{array}{l}4.23 / \\
0.696\end{array}$ \\
\hline $\begin{array}{l}\text { Course materials } \\
\text { (help understand topics } \\
\text { covered) }\end{array}$ & $\begin{array}{l}0.4 \\
(1)\end{array}$ & $1.1(3)$ & $\begin{array}{l}11.3 \\
(30)\end{array}$ & $\begin{array}{l}60.8 \\
(161)\end{array}$ & $26.4(70)$ & $\begin{array}{l}4.16 / \\
0.667\end{array}$ \\
\hline $\begin{array}{l}\text { Course activities } \\
\text { (enhance understanding } \\
\text { of topics covered) }\end{array}$ & $\begin{array}{l}0.4 \\
(1)\end{array}$ & $1.1(3)$ & $\begin{array}{l}11.7 \\
(31)\end{array}$ & $\begin{array}{l}61.5 \\
(163)\end{array}$ & $25.3(67)$ & $\begin{array}{l}4.14 / \\
0.664\end{array}$ \\
\hline $\begin{array}{l}\text { Course materials } \\
\text { (meet learning needs) }\end{array}$ & $\begin{array}{l}0.4 \\
(1)\end{array}$ & $1.9(5)$ & $9.1(24)$ & $\begin{array}{l}64.9 \\
(172)\end{array}$ & $23.4(62)$ & $\begin{array}{l}4.14 / \\
0.654\end{array}$ \\
\hline $\begin{array}{l}\text { Course activities } \\
\text { (meet learning needs) }\end{array}$ & $\begin{array}{l}0.4 \\
(1)^{2}\end{array}$ & $1.1(3)$ & $\begin{array}{l}12.5 \\
(33) \\
\end{array}$ & $\begin{array}{l}59.2 \\
(157) \\
\end{array}$ & $26.4(70)$ & $\begin{array}{l}4.15 / \\
0.678 \\
\end{array}$ \\
\hline $\begin{array}{l}\text { Entire content } \\
\text { (facilitate revision) }\end{array}$ & $\begin{array}{l}0.4 \\
(1)^{2}\end{array}$ & $1.1(3)$ & $\begin{array}{l}16.2 \\
(43)\end{array}$ & $\begin{array}{l}58.1 \\
(154)\end{array}$ & $23.8(63)$ & $\begin{array}{l}4.08 / \\
0.703\end{array}$ \\
\hline $\begin{array}{l}\text { Entire content } \\
\text { (was satisfactory) }\end{array}$ & $\begin{array}{l}0.4 \\
(1)\end{array}$ & $1.1(3)$ & $\begin{array}{l}11.3 \\
(30) \\
\end{array}$ & $\begin{array}{l}59.6 \\
(158)\end{array}$ & $27.5(73)$ & $\begin{array}{l}4.17 / \\
0.673\end{array}$ \\
\hline $\begin{array}{l}\text { Total number of } \\
\text { respondents (\%) }\end{array}$ & $\begin{array}{c}265 \\
(100 \%)\end{array}$ & & & & & \\
\hline
\end{tabular}

The researchers had collected feedback regarding specific areas of its contents in order to cater to the needs of learners of different learning styles.

A total of 265 students participated in the multimedia e-learning materials Introductory Mandarin 1 learning program. These students made up the research sample. Table 3 shows the respondents' feedback regarding the contents of multimedia e-learning materials after having used the product for one semester at home. $90.9 \%$ of the respondents agreed that the e-learning materials contents were in compliance with the Mandarin I syllabus, with clear learning objectives (87.9\%) of each topic/lesson learning objectives, clear and complete topic syllabus (87.5\%) and support materials such as exercises, Internet link, notes, et cetera (86.8\%) and course materials (video teaching, teaching notes, grammar, vocabulary, dialogues, and videos) that helped them gain better understanding of the contents and course activities (quiz, written exercises, audio presentation/exercises). These also benefited them to enhance the 
understanding of the contents (87.2\%) and course activities (86.8\%). In addition, the course materials $(85.6 \%)$ and course activities $(88.3 \%)$ provided also meet the students' learning needs. $87.1 \%$ of the respondents said that the entire content helped them to understand Mandarin I topics and helped them to do revision (81.9\%) in the order individually preferred.

The descriptive analysis, mean and standard deviation were also calculated, and can be seen in Table 3. Table 3 presents the measures of students' perspectives of the multimedia elearning Introductory Mandarin 1 contents. The respondents had a positive opinion of the elearning contents, as suggested by more than average (4 to 4.48) mean values for the measures. Furthermore, the standard deviation (SD) for all measures showed less than 1, indicating that there was little variation among respondents' opinions to each measure.

All in all, in accordance with the data gathered from students, the content of Introductory Mandarin 1 did meet the needs of the learner. The Introductory Mandarin 1 is aligned with the Mandarin 1 syllabus, the course materials and course activities provided were suitable for the learners, clear objective was given to the learners, and the Introductory Mandarin 1 also was attached with extra support materials to help students do revisions after classes. In other words, the contents of Introductory Mandarin 1 helped learners with their Mandarin 1 acquisition as majority of students showed their satisfaction with its overall content. As indicated by Subramaniam et al (2019), creating an effective learning environment will provide a positive learning experience for learners. In line with this, it will promote learners' self-efficacy (Alonso-Mencía et al., 2021). 
INTERNATIONAL JOURNAL OF ACADEMIC RESEARCH IN PROGRESSIVE EDUCATION AND

DEVELOPMENT

Vol. 10, No. 3, 2021, E-ISSN: 2226-6348 @ 2021 HRMARS

Delivery of multimedia e-learning materials Introductory Mandarin 1

Table 4

Approach to multimedia e-learning materials delivery

\begin{tabular}{|c|c|c|c|c|c|c|}
\hline Item & $\begin{array}{l}\text { Strongl } \\
\text { y } \\
\text { Disagre } \\
\text { e } \\
\% \text { (no.) }\end{array}$ & $\begin{array}{l}\text { Disagree } \\
\% \text { (no.) }\end{array}$ & $\begin{array}{l}\text { Unsure } \\
\% \text { (no.) }\end{array}$ & $\begin{array}{l}\text { Agree } \\
\% \text { (no.) }\end{array}$ & $\begin{array}{l}\text { Strongl } \\
\text { y Agree } \\
\% \text { (no.) }\end{array}$ & $\begin{array}{l}\text { Mean/ } \\
\text { SD }\end{array}$ \\
\hline $\begin{array}{l}\text { Presentation method suits } \\
\text { students' learning styles }\end{array}$ & $0.4(1)$ & $0.4(1)$ & $\begin{array}{l}16.6 \\
(44)\end{array}$ & $\begin{array}{l}62.3 \\
(165)\end{array}$ & $\begin{array}{l}20.4 \\
(54)\end{array}$ & $\begin{array}{l}4.02 / \\
0.648\end{array}$ \\
\hline Course is well designed & $0.4(1)$ & $0.4(1)$ & $\begin{array}{l}12.8 \\
(34) \\
\end{array}$ & $\begin{array}{l}65.7 \\
(174) \\
\end{array}$ & $\begin{array}{l}20.8 \\
(55) \\
\end{array}$ & $\begin{array}{l}4.06 / \\
0.619 \\
\end{array}$ \\
\hline $\begin{array}{l}\text { Learning through } \mathrm{MOOC} \\
\text { meets learning needs }\end{array}$ & $0.4(1)$ & $0.4(1)$ & $\begin{array}{l}15.5 \\
(41) \\
\end{array}$ & $\begin{array}{l}65.7 \\
(174) \\
\end{array}$ & $\begin{array}{l}18.1 \\
(48)\end{array}$ & $\begin{array}{l}4.01 / \\
0.622 \\
\end{array}$ \\
\hline $\begin{array}{l}\begin{array}{l}\text { Sequence of learning } \\
\text { helps }\end{array} \\
\begin{array}{l}\text { undivities } \\
\text { subject matter }\end{array}\end{array}$ & $0.4(1)$ & $0.4(1)$ & $\begin{array}{l}13.6 \\
(36)\end{array}$ & $66(175)$ & $\begin{array}{l}19.6 \\
(52)\end{array}$ & $\begin{array}{l}4.04 / \\
0.617\end{array}$ \\
\hline $\begin{array}{l}\text { Learning schedule } \\
\text { suits learning pace }\end{array}$ & $0.4(1)$ & $0.4(1)$ & $\begin{array}{l}16.2 \\
(43)\end{array}$ & $\begin{array}{l}64.9 \\
(172)\end{array}$ & $\begin{array}{l}18.1 \\
(48)\end{array}$ & $\begin{array}{l}4.00 / \\
0.628\end{array}$ \\
\hline $\begin{array}{l}\text { Design elements: } \\
\text { texts, graphics, animations } \\
\text { (enhance learning) }\end{array}$ & $0.4(1)$ & $0.8(2)$ & $\begin{array}{l}12.5 \\
(33)\end{array}$ & $\begin{array}{l}64.9 \\
(172)\end{array}$ & $\begin{array}{l}21.5 \\
(57)\end{array}$ & $\begin{array}{l}4.06 / \\
0.633\end{array}$ \\
\hline $\begin{array}{l}\text { Audio and video (enable } \\
\text { learners to enhance } \\
\text { vocabulary and phrases) }\end{array}$ & $0.4(1)$ & - & $\begin{array}{l}11.7 \\
(31)\end{array}$ & $\begin{array}{l}66.8 \\
(177)\end{array}$ & $\begin{array}{l}21.1 \\
(56)\end{array}$ & $\begin{array}{l}4.08 / \\
0.597\end{array}$ \\
\hline $\begin{array}{l}\text { Content presentation } \\
\text { (systematic and easy to } \\
\text { follow) }\end{array}$ & $0.4(1)$ & $0.4(1)$ & $\begin{array}{l}15.5 \\
(41)\end{array}$ & $\begin{array}{l}63.4 \\
(168)\end{array}$ & $\begin{array}{l}20.4 \\
(54)\end{array}$ & $\begin{array}{l}4.03 / \\
0.639\end{array}$ \\
\hline $\begin{array}{l}\text { Exercises } \\
\text { (help learning) }\end{array}$ & - & - & $\begin{array}{l}13.6 \\
(36)\end{array}$ & $\begin{array}{l}63.8 \\
(169) \\
\end{array}$ & $\begin{array}{l}22.6 \\
(60) \\
\end{array}$ & $\begin{array}{l}4.09 / \\
0.596\end{array}$ \\
\hline $\begin{array}{l}\text { Entire content (promote } \\
\text { understanding of lesson) }\end{array}$ & $0.4(1)$ & - & $\begin{array}{l}11.3 \\
(30)\end{array}$ & $\begin{array}{l}65.3 \\
(173)\end{array}$ & $23(61)$ & $\begin{array}{l}4.11 / \\
0.606\end{array}$ \\
\hline $\begin{array}{l}\text { Total number of } \\
\text { respondents (\%) }\end{array}$ & $\begin{array}{l}265 \\
(100 \%)\end{array}$ & & & & & \\
\hline
\end{tabular}

The researchers intended to find out whether students found the specially-designed multimedia e-learning materials helpful to the learning of Elementary Mandarin I. Respondents were to comment on the suitability of the product by considering its compliance with its method of delivery and content presentation, as well as the role of the design elements in learning Mandarin. $82.7 \%$ thought the product could cater to the learning styles of most students. $86.5 \%$ agreed that the $\mathrm{MOOC}$ course is well designed and learning through MOOC meets their learning needs (84.8\%). Besides that, the sequence of learning activities provided them better understanding of the subject matter (85.6\%). Meanwhile, the 14 weeks 
learning schedule (course plan) suits their learning pace as students can plan their learning schedule by referring to the course plan (83\%). This is supported by Rabin et al. (2020) who mentioned that deploying that goal setting, time management, and study strategy will assist learner to manage and plan study time for learning.

86.4\% of the respondents agreed that the use of e-learning materials that incorporated some design elements (text, graphics, colour and animation) into the learning enhanced the process of teaching and learning. $86.4 \%$ of the respondents found the video clips and audios in the elearning materials helpful as they could enhance their comprehension of the context and the materials were used effectively and enabled learners to focus on the content, vocabulary and phrases.

Nearly all of the respondents stated that the entire delivery of contents promoted more understanding of the lesson (88.3\%) and the presentation of the content was systematic (83.8\%). $86.4 \%$ of the respondents were satisfied with the exercises given in the multimedia e-learning materials (MOOC) as they were brief, realistic, and sufficient to help them understand the topics. Very few respondents (0.5\%-1\%) were disappointed with the elearning materials MOOC delivery. However, a few respondents (11.3\%-16.6\%) were "not sure" whether e-learning materials MOOC delivery could enhance the process of the teaching and learning of Elementary Mandarin I.

As shown in Table 4, the mean and standard deviation measure students' perceptions of the e-learning materials. Respondents had a positive opinion of the $\mathrm{MOOC}$ e-learning materials related to the teaching and learning delivery as suggested by the mean values (4.00 to 4.11) for the measures. The standard deviation (SD) for all measures ranged from 0.597 to 0.633 , suggesting that there was little variation among the respondents' opinion for each measure.

Table 5

Reliability Analysis for the Summated Score

\begin{tabular}{llll}
\hline $\begin{array}{l}\text { Multimedia E-learning Materials } \\
\text { Introductory Mandarin 1 }\end{array}$ & Mean & $\begin{array}{l}\text { Standard } \\
\text { Deviation }\end{array}$ & $\begin{array}{l}\text { Cronbach's } \\
\text { Alpha }\end{array}$ \\
\hline Content (10 items) & 4.13 & .577 & 0.952 \\
\hline $\begin{array}{l}\text { Teaching \& learning delivery approach (10 } \\
\text { items) }\end{array}$ & 4.02 & .491 & 0.934 \\
\hline
\end{tabular}

The reliability analysis was conducted to ensure the internal validity and consistency of the items or indicators used for each variable. Table 5 shows the Cronbach's alpha values for the MOOC multimedia e-learning materials. The suggested accepted values for Cronbach's alpha from 0.6 to 0.7 were deemed the lower limit of acceptability. An alpha of more than 0.7 would show that the items are homogeneous and measuring the same constant (Hair et al., 1998) and all factors in Table 5 exhibit a high degree of internal consistency as the alpha values are more than 0.7 . The summated score of mean values for perceptions of usability of MOOC multimedia e-learning materials is quite similar to each other and the standard deviation values across the summated scores do not deviate much, suggesting homogeneity among the perceptions score. 
From the overall feedback of the students, the researchers of this study can conclude that the contents and design of Multimedia e-learning Introductory Mandarin 1 were appropriate and suitable to use as an educational e-multimedia Mandarin language via MOOC.

\section{Conclusion}

This research investigated the learners' feedback in relation to the usability of the selfdeveloped Multimedia e-learning Introductory Mandarin I MOOC in its contents and design. The research has confirmed the usability of Multimedia e-learning Introductory Mandarin I $M O O C$ as a supplementary e-instructional tool in the teaching and learning of Elementary Mandarin 1 for UiTM students. Most of the students perceived that the Introductory Mandarin 1 is aligned with the Mandarin 1 syllabus, the course materials (video teaching, teaching notes, grammar, vocabulary, dialogues and videos), course activities (quiz, written exercises, audio presentation/exercises) and extra support materials provided were suitable for the learners. A clear objective was also given to the learners in which helped them to do revisions after classes. On the other hand, the use of Introductory Mandarin 1 served as a method to strengthen learners' four language skills (speaking, listening, reading, and writing) and to improve learners' vocabularies with visual-verbal-auditory features. This finding corresponds to the finding indicated by Liu, Kang, and McKelroy (2015) that quality of the materials is an important consideration for students and that interactive course content can increase learner-content interaction and overall satisfaction with the MOOC course (Bahaa, 2017; Goh et al., 2018).

The combination of multimedia elements (video, audio, text, animation, and image) in Introductory Mandarin 1 was accepted as effective in enhancing the learning process of Elementary Mandarin 1. This correlation with the findings of other researchers such as Liu et al. (2015) indicated that good designs can help promote MOOC participants' levels of engagement and allow effective pedagogical principles to benefit learners. Besides that, the design of the interface for a MOOC delivery platform is crucial in designing a MOOC product. Watson et al. (2016) outlined that instructional activities such as video teaching, relevant sources, and exercises play an important role in MOOC course design. Donald et al. (2017) mentioned that the video is an integral part of many MOOCs. Producing broadcast-quality videos and animations will promote $\mathrm{MOOC}$ to be more interactive. In addition, Introductory Mandarin 1 also promotes self-regulated learning, autonomy learning, ODL (Online Distance Learning) and flexible learning outside the classroom since students who join the Introductory Mandarin 1 course are also able to review their syllabus at their own pace via digital devices, and they can manipulate the contents at anytime and anywhere at their own convenience. This finding is aligned with Rabin et al. (2020) who stated that course designers and facilitators should help MOOC learners to self-regulate their learning process and help them promote their feeling of self-efficacy (Jamal et al., 2020; Alonso-Mencía et al., 2021).

It is hoped that the establishment of effective interactive e-learning courseware via MOOCs will create a flexible, enjoyable, flip, and active learning environment for learners who learn Mandarin as foreign language or third language. Furthermore, since the COVID-19 pandemic, the education sector has restructured face-to-face learning into online distance learning $(\mathrm{ODL})$. In keeping with the current mode of delivery, MOOC Introductory Mandarin I can be served as an online learning material/platform in teaching and learning Mandarin. 
The outcomes of this research suggest possible future research which focus on adding in elements of assessments into MOOC or the feasibility of turning MOOC materials into microcredential courses. In UiTM, the Institute of Continuing Education \& Professional Studies (iCEPS) has recently encouraged this move to turn MOOC materials into micro-credential courses to provide a certification-style qualification for individuals to study a particular area including languages to improve individual's skill and competences. This is in line with the aims of Malaysian Qualifications Agency (MQA) to unbundle and market accredited programmes offered at higher education institutions, allowing non-traditional learners access to education in order to realise the nation's lifelong and life-wide learning goals (Malaysian Qualifications Agency, 2020).

\section{References}

Alonso-Mencía, M. E., Alario-Hoyos, C., Estévez-Ayres, I., \& Kloos, D. C. (2021). Analysing selfregulated learning strategies of $\mathrm{MOOC}$ learners through self-reported data. Australasian Journal of Educational Technology, 37(3), 56-70. https://doi.org/10.14742/ajet.6150

Bahaa, G. G. (2017) Learner Satisfaction with Massive Open Online Courses, American Journal of Distance Education, 31:2, 98-111, DOI:10.1080/08923647.2017.1300462

Carver, L., \& Harrison, L. M. (2013). MOOCs and democratic education. Liberal Education, 99(4). https://aacu.org/liberaleducation/2013/fall/carver-harrison.

Donald, C., Ramsay, E., \& Joerg, I. (2017). Designing for Learning in a MOOC: A Pedagogical Model in Disguise. Journal of Perspectives in Applied Academic Practice, 5 (3).90-101.

Gagne, R. M. (1985). The Conditions of Learning (4 ${ }^{\text {th }}$ ed.). Holt, Rinehart \& Winston.

Gagne, R. M., Briggs, L. J., \& Wager, W. W. (1992). Principles of Instructional Design (4th Ed.). Harcourt, Brace, Jovanovich College Publishers.

Goh, W. W., Wong, S. Y., Ayub, E. (2018). The Effectiveness of MOOC Among Learners Based on Kirkpatrick's Model. In Tang, S.F., Cheah, S. E., Redesigning Learning for Greater Social Impact (pp.313-323). Springer. https://doi.org/10.1007/978-981-10-4223-2

Jamal, N. F., Ghafar, N. M. A., Ismail, I. L., Chek, A. M. Z., \& Baharuddin, M. S. (2020). Learning Mathematical Statistics in Massive Open Online Courses (MOOCs). International Journal of Modern Education, 2(5), 38-45. DOI: 10.35631/IJMOE.25005

Liu, M., Kang, J., \& McKelroy, E. (2015) Examining learners' perspective of taking a MOOC: reasons, excitement, and perception of usefulness. Educational Media International, 52:2, 129-146, DOI:10.1080/09523987.2015.1053289

Malaysian Qualifications Agency. (2020). Guidelines to Good Practices: Micro-credentials (1 ${ }^{\text {st }}$ ed.). Malaysian Qualifications Agency 2020. Retrieved from https://www2.mqa.gov.my/qad/v2/garispanduan/2020/GGP\%20Microcredentials\%20July\%202020.pdf

Ministry of Education Malaysia. (2015). Malaysia Education Blueprint 2015-2025 (Higher Education). Ministry of Education Malaysia.

Ministry of education. (2017). Garis Panduan Pembangunan dan Penyampaian MOOC Malaysia.

Pappas, C. (2015). How to Apply Gagné's 9 Events of Instruction In eLearning [Blog Post]. https://elearningindustry.com/how-to-apply-gagnes-9-events-of-instruction-inelearning 
Shah, D. (2018). Class Central Learner Survey (2017): MOOC Users High Educated, Have Experienced Career Benefits [Blog Post]. https://www.classcentral.com/report/mooc-stats-2017/

Waite, M., Mackness, J., Roberts, G., \& Lovegrove, E. (2013). Liminal participants and skilled orienteers: Learner participation in a MOOC for new lecturers. MERLOT Journal of Online Learning \& Teaching, 9, 200-215.

Watson, S. L., Loizzo, J., Watson, W. R., Mueller, C., Lim, J., \& Ertmer, P. A. (2016). Instructional design, facilitation, and perceived learning outcomes: an exploratory case study of a human trafficking MOOC for attitudinal change. Education Tech Research Dev. DOI 10.1007/s11423-016-9457-2 